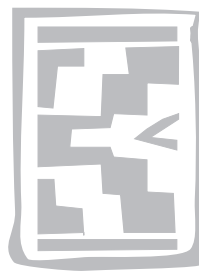

\title{
African swine fever
}

\author{
MARY-LOUISE PENRITH ${ }^{1,2}$ \\ 1 Department of Veterinary Tropical Diseases, Faculty of Veterinary Science, University of Pretoria \\ 2 TADScientific, 40 Thomson Street, Colbyn, 0083 Pretoria
}

\begin{abstract}
PENRITH, M-L. 2009. African swine fever. Onderstepoort Journal of Veterinary Research, 76:91-95

African swine fever (ASF) is a devastating haemorrhagic fever of pigs that causes up to $100 \%$ mortality, for which there is no vaccine. It is caused by a unique DNA virus that is maintained in an ancient cycle between warthogs and argasid ticks, making it the only known DNA arbovirus. ASF has a high potential for transboundary spread, and has twice been transported from Africa to other continentsEurope and subsequently the Caribbean and Brazil $(1957,1959)$ and the Caucasus (2007). It is also a devastating constraint for pig production in Africa. Research at Onderstepoort Veterinary Institute has made and is making important contributions to knowledge of this disease, focusing on the cycle in warthogs and tampans and transmission from that cycle to domestic pigs, resistance to its effects in domestic pigs, and the molecular genetic characterisation and epidemiology of the virus.
\end{abstract}

\section{INTRODUCTION}

African swine fever (ASF) is a devastating haemorrhagic fever of pigs that causes up to $100 \%$ mortality (Penrith, Thomson \& Bastos 2004b). It is arguably the most serious constraint for pig production wherever it occurs. It is endemic in most sub-Saharan African countries where pigs are produced, and where pigs, because of their high reproductive potential and ability to convert low quality feed into high quality protein, could play a crucial role in poverty alleviation (Penrith et al. 2004b). It is also of great importance because of its remarkable potential for transboundary spread, which was amply demonstrated in the second half of the last century when it escaped from Africa to affect several countries in western Europe, with trans-Atlantic spread to the Caribbean and Brazil, and again in 2007 when it appeared in the Caucasus, with subsequent involvement of all the countries in that region (Wilkinson 1989; Penrith et al. 2004b; World Organisation for Animal Health 2007, 2008). In spite of ongoing efforts, to date there is no vaccine against ASF. New generation vaccines may possibly offer some hope for the future (Lewis, Zsak, Burrage, Lu, Kutish, Neilan \& Rock 2000), but there are still many challenges (Neilan, Zsak, Lu, Burrage, Kutish \& Rock 2004; Argilaguet, Pérez-Martin, Gallardo, Nofrarias, Pujols, Pérez-Filgueira, Blanco, Salguero, Escribano \& Rodriguez 2008).

\section{DISTRIBUTION AND EPIDEMIOLOGY OF ASF}

ASF is presumed to have evolved in southern and eastern Africa, where a sylvatic cycle of maintenance and transmission involving the natural hosts and vectors, namely warthogs (Phacochoerus spp.) and argasid ticks (Ornithodoros moubata complex), occurs (Penrith et al. 2004b). The ticks inhabit the burrows of warthogs and feed on their blood, transmitting the virus in the process. Warthogs are impervious to the pathogenic effects of the virus, do not develop viraemia and exhibit no clinical signs, 
although the virus may be extracted from their lymphoid tissues. However, neonatal warthogs that spend the first few weeks of their lives in the burrows develop sufficiently high viraemia to infect new ticks, although they do not develop clinical disease (Thomson 1985). The ticks are able to maintain and transmit the virus to pigs for several years (OleagaPérez, Pérez-Sanchez \& Encinas-Grandes 1990; Astigarraga, Oleaga-Pérez, Pérez-Sanchez \& Encinas-Grandes 1995) and they also transmit the virus transovarially, transstadially and sexually (Plowright, Parker \& Pierce 1969; Plowright, Perry \& Peirce 1970; Plowright, Perry \& Greig 1974; Rennie, Wilkinson \& Mellor 2001).

Like warthogs, the other wild African pigs (Potamochoerus spp., Hylochoerus meinertzhageni) are susceptible to infection with ASF virus but not to its pathogenic effects (Plowright, Thomson \& Neser 1994; Anderson, Hutchings, Mukarati \& Wilkinson 1998). The introduction of domestic pigs into the region, probably first in Angola and Mozambique, resulted in a susceptible host that almost invariably died of the disease. The occurrence of the disease in areas where $O$. moubata complex ticks inhabited pig sties allowed the establishment of a domestic cycle of viral circulation, and over time in some areas pigs developed a higher degree of resistance, resulting in lower mortality, although the virulence of the viruses infecting them remained unchanged (Haresnape, Lungu \& Mamu 1985, 1987; Penrith, Thomson, Bastos, Phiri, Lubisi, Botha, Esterhuysen, Du Plessis, Macome \& Pinto 2004c). How and when the disease spread to West Africa is uncertain, but in spite of the absence of Ornithodoros spp. in association with either pigs or warthogs, ASF became endemic in Senegal, probably Guinea Bissau, and Cameroon (Penrith et al. 2004b). Since no long term carrier state has been demonstrated in recovered pigs, and there is considerable evidence that such a state does not occur (Valadão 1969; Wilkinson, Wardley \& Williams 1983; Pujols-Romeu, BadiolaSaiz, Pérez de Rozas, Segura-Cardona, SacoGalvany 1991; Penrith et al. 2004c). Viral circulation in these countries depends upon an endless supply of naïve pigs to infect, a circumstance that is strongly favoured by traditional free-ranging pig husbandry systems (Penrith, Lopes Pereira, Lopes da Silva, Quembo, Nhamusso \& Banze 2007).

In 1957 and again in 1959, ASF spread from Angola to Portugal, probably in infected pork subsequently fed as swill (Wilkinson 1989). The disease became established in the Iberian Peninsula, from which it was only eradicated in 1994 (Davies 1994). The presence in pig sties of a suitable tick host, Ornithodoros erraticus, helped to prolong the time taken for eradication (Pérez-Sánchez, Astigarraga, OleagaSánchez \& Encinas Grandes 1994), and a small outbreak related to ticks in abandoned pig sties in Portugal occurred in 1999 (Basto, Nix, Boinas, Mendes, Silva, Cartaxeiro, Portugal, Leitão, Dixon \& Martins 2006). During the 1970 s and 1980 s several countries in western Europe experienced outbreaks that were quickly eradicated, but ASF persists in Sardinia, which became infected in 1987, owing to circulation in dense populations of free-ranging domestic pigs with occasional involvement of wild boar as well (Manelli, Sotgia, Patta, Oggiano, Carboni, Cossu \& Laddomada 1998). During the same period outbreaks occurred in Cuba, Hispaniola (Haiti and Dominican Republic), and Brazil, and were only eradicated at considerable cost (Butler \& Gibbs 1984; Lyra 2006).

From 1994 Africa experienced an upsurge of ASF that resulted in a pandemic that swept through several West African countries never previously affected (El-Hicheri, Gómez-Tejedor, Penrith, Davies, Douati, Edoukou \& Wojciechowski 1998; World Organisation for Animal Health 1996-2002; Otesile, Ajuwape, Odemuyiwa, Akpavie, Olaifa, Odaibo, Olaleye \& Adetosoye 2005). Additionally, Kenya experienced outbreaks for the first time in 30 years, the previously ASF-free southern provinces of Mozambique suffered major outbreaks, and the island of Madagascar became infected for the first time in 1997 (Roger, Rantovonjato, Vola \& Uilenberg 2001; Penrith et al. 2004b). Most of the affected countries had difficulty in controlling the disease and even those in which ASF has not become endemic experience sporadic incursions. Mauritius was infected, probably from Madagascar, in 2007 (World Organisation for Animal Health 2007).

In 2007 a dramatic change in distribution occurred when ASF was confirmed in the Republic of Georgia, with subsequent spread to Armenia, Azerbaijan and Russia. The source of the virus, a Genotype II virus previously described from Mozambique and Madagascar (Bastos, Penrith, Macome, Pinto \& Thomson 2004) that is not related to the Genotype I virus that previously invaded Europe, is likely to be galley waste that was available to free-ranging pigs around the port of Poti on the Georgian Black Sea coast (unpublished reports to FAO 2007). The fact that ASF was confirmed in dead wild boars in Chechnya, on the border with Georgia (World Organisation for Animal Health 2007), is a matter for concern, since it complicates control and eradication. 


\section{MILESTONES IN RESEARCH ON ASF}

ASF was first recognised as a disease entity distinct from classical swine fever and related to contact between domestic pigs and warthogs in Kenya (Montgomery 1921). The ability of Ornithodoros ticks to maintain and transmit the virus was first described in Spain by Sanchez-Botija in 1963, and this led to the confirmation of the pivotal role played by $O$. moubata in the sylvatic cycle in Africa (Plowright et al. 1969). Studies by Haresnape and her colleagues (Haresnape et al. 1985, 1987) in Malawi revealed the existence of a domestic cycle involving Ornithodoros in a population of pigs of which a fairly high proportion had antibodies to ASF yet were clearly healthy and productive.

All ASF viruses are regarded as belonging to a single serotype, since attempts to distinguish them by serotyping proved unreliable (Vigário, Terrinha \& Moura Nunes 1974). The use of restriction fragment length polymorphism (RFLP) made it possible to study the genetic relationships between ASF viruses (Wesley \& Tuthill 1984; Blasco, Aguero, Amendral \& Viñuela 1989). Nucleotide sequencing using the p72 structural protein has permitted further advances in the genetic characterization of ASF viruses, which has proven extremely useful in indicating the possible or probable origin of outbreak viruses and the relationships between outbreaks (Bastos, Penrith, Cruciere, Edrich, Hutchings, Roger, CouacyHyman \& Thomson 2003; Bastos et al. 2004).

\section{PROSPECTS FOR CONTROL}

In the future, it may be possible to improve control of ASF by the use of effective new generation vaccines, and/or by exploiting the natural resistance that has been demonstrated to occur in some populations of domestic pigs. In the meantime, we are faced with the difficulty that the conventional control methods of 'stamping out' and destroying large numbers of pigs is increasingly unacceptable for ethical and environmental reasons and is in fact impossible to implement successfully in countries where resources in terms of both finance and veterinary services are limited (Penrith \& Thomson 2004a). The only viable alternative is farmer-based control, where the focus is on prevention. A directly transmitted disease like ASF can be adequately controlled by biosecurity measures, but the application of these in the areas most affected by ASF implies a change from traditional extensive low input husbandry to more intensive systems that place a higher demand on the producer (Penrith et al., 2007). It is likely that such a change would need to be market driven rather than depending entirely on considerations of disease prevention.

\section{THE ONDERSTEPOORT CONTRIBUTION TO ASF RESEARCH AND CONTROL}

ASF was first reported in South Africa in 1928 (Steyn 1928, 1932; De Kock, Robinson \& Keppel 1940). Onderstepoort has made valuable contributions in terms of research and has also provided international support for control of ASF. Studies carried out at Onderstepoort contributed to knowledge of the pathogenic, immunogenic and haemadsorbing properties of ASF viruses and in particular provided considerable information about the sylvatic cycle and the respective roles of warthogs and ticks in maintenance and transmission of the virus (Thomson, Gainaru \& Van Dellen 1979; Thomson, Gainaru, Lewis, Biggs, Nevill, Van der Pypekamp, Gerber, Esterhuysen, Bengis, Bezuidenhout \& Condy 1980; 1981; Thomson 1985). When ASF emerged as a serious and widespread problem for traditional pig producers throughout sub-Saharan Africa, research was initiated into the nature of natural resistance evident in the domestic pig population in north-western Mozambique, adjacent to the district in Malawi where a similar situation was described (Haresnape et al. 1985, 1987). It was hoped that a genetic basis for resistance could be established, but the results indicated that resistance is apparently not inherited (Penrith et al. 2004c).

The project provided impetus for molecular genetic studies on ASF virus to be initiated at Onderstepoort (Bastos et al. 2003, 2004). These studies have been continued and expanded (Lubisi, Bastos, Dwarka \& Vosloo 2005, 2007), and there are currently several internationally funded projects under way at OVI that are making contributions to the molecular epidemiology of ASF, especially in eastern and southern Africa, to improved diagnosis of ASF and, perhaps, eventually to the development of an effective vaccine against this devastating disease.

In response to the ASF crisis in sub-Saharan Africa that occurred in the 1990s, the Food and Agriculture Organization of United Nations provided technical support for diagnosis and control to affected countries that applied for it. The Onderstepoort Veterinary Institute provided expert consultants for technical cooperation projects in Mozambique, Kenya, Côte d'Ivoire, Benin, Cabo Verde, Ghana, Gambia and Mauritius during the period 1995-2007. 


\section{REFERENCES}

ANDERSON, E.C., HUTCHINGS, G.H., MUKARATI, N. \& WILKINSON, P.J. 1998. African swine fever virus infection of the bushpig (Potamochoerus porcus) and its significance in the epidemiology of the disease. Veterinary Microbiology, 62:115.

ARGILAGUET, J.M., PÉREZ-MARTIN, E., GALLARDO, C., NOFRARIAS, M., PUJOLS, J., PÉREZ-FILGUEIRA, M., BLANCO, F., SALGUERO, J., ESCRIBANO, J.M. \& RODRIGUEZ, F. 2008. DNA vaccines against African swine fever virus: Relevance of humoral and cellular responses in protection. Proceedings of the $20^{\text {th }}$ International Pig Veterinary Society Congress, Durban, South Africa, 22-26 June 2008: 81.

ASTIGARRAGA, A., OLEAGA-PÉREZ, A., PÉREZ-SANCHEZ, R. \& ENCINAS-GRANDES, A.1995. A study of the vaccinal value of various extracts of concealed antigens and salivary gland extracts against Ornithodoros erraticus and Ornithodoros moubata. Veterinary Parasitology, 60:133-147.

BASTO, A.P., PORTUGAL, R.S., NIX, R.J., CARTAXEIRO, C., BOINAS, F., DIXON, L.K., LEITÃO, A. \& MARTINS, C. 2006. Development of a nested PCR and its internal control for the detection of African swine fever virus (ASFV) in Ornithodoros erraticus. Archives of Virology, 151: 819-826.

BASTOS, A.D.S, PENRITH, M-L., CRUCIÈRE, C., EDRICH, J.L., HUTCHINGS, G., ROGER, F., COUACY-HYMAN, E. \& THOMSON, G.R. 2003. Genotyping field strains of African swine fever virus by partial p72 gene characterisation. Archives of Virology, 148:693-706.

BASTOS, A.D.S., PENRITH, M-L., MACOME, F., PINTO, F. \& THOMSON, G.R. 2004. Co-circulation of two genetically distinct viruses in the 1998/9 African swine fever outbreak in Mozambique: no evidence for individual infection. Veterinary Microbiology, 103:169-182.

BLASCO, R., AGUERO, M., AMENDRAL J.M. \& VIÑUELA, E. 1989. Variable and constant regions in African swine fever virus DNA. Virology, 168:330-338.

BORCA, M.V., IRUSTA, P., CARRILLO, C., AFONSO, C.L., BURRAGE, T. \& ROCK, D.L. 1994. African swine fever virus structural protein p72 contains a conformational neutralizing epitope. Virology, 201:413-418.

BUTLER, J.F. \& GIBBS, E.P.J. 1984. Distribution of potential soft tick vectors of African swine fever in the Caribbean region (Acari: Argasidae). Preventive Veterinary Medicine, 2:63-70

DAVIES, G. 1994. Eradication of epidemic pig diseases in the European Union. Veterinary Record, 135:567-568.

DE KOCK, G., ROBINSON, E.M. \& KEPPEL, J.J.G. 1940. Swine fever in South Africa. Onderstepoort Journal of Veterinary Science and Animal Industry, 14:31-93.

EL-HICHERI, K., GÓMEZ-TEJEDOR, C., PENRITH, M-L., DAVIES, G., DOUATI, A., EDOUKOU, G.D. \& WOJCIECHOWSKI, K. 1998. L'épizootie de peste porcine africaine de 1996 en Côte d'Ivoire. Revue Scientifique et Technique, Office International des Epizooties 17: 660-673.

LEWIS, T., ZSAK, L., BURRAGE, T.G., LU, Z., KUTISH, G.F., NEILAN, J.G. \& ROCK, D.L. 2000. An African swine fever virus ERV1-ALR homologue, 9GL, affects virion maturation and viral growth in macrophages and viral virulence in swine. Journal of Virology, 74:1275-1285.

HARESNAPE, J.M. LUNGU, S.A.M. \& MAMU, F.D. 1985. A four year survey of African swine fever in Malawi. Jornal of $\mathrm{Hy}$ giene, Cambridge, 95:309-323.

HARESNAPE, J.M. LUNGU, S.A.M. \& MAMU, F.D. 1987. An updated survey of African swine fever in Malawi. Epidemiology and Infection, 99:723-732.
LUBISI, B.A., BASTOS, A.D.S., DWARKA, R.M. \& VOSLOO, W. 2005. Molecular epidemiology of African swine fever in East Africa. Archives of Virology, 150:2439-2452.

LUBISI, B.A., BASTOS, A.D.S., DWARKA, R.M. \& VOSLOO, W. 2007. Intra-genotypic resolution of African swine fever viruses from an East African domestic pig cycle: a combined p72CVR approach. Virus Genes, 35:729-735.

LYRA, T.M.P. 2006. La erradicación de la peste porcina africana en el Brasil, 1978-1984. Revue scientifique et technique, Office International des Épizooties, 25:93-103.

MANELLI, A., SOTGIA, S., PATTA, C., OGGIANO, A., CARBONI, A., COSSU, P. \& LADDOMADA, A. 1998. Temporal and spatial patterns of African swine fever in Sardinia. Preventive Veterinary Medicine, 35:297-306.

MONTGOMERY, R.E. 1921. On a form of swine fever occurring in British East Africa (Kenya Colony). Journal of Comparative Pathology, 34:154-191; 243-262.

NEILAN, J.G., ZSAK, L., LU, Z., BURRAGE, T.G., KUTISH, G.F. \& ROCK, D.L. 2004. Neutralizing antibodies to African swine fever virus proteins p30, p54 and p72 are not sufficient for antibody-mediated protection. Virology, 319:337-342.

OLEAGA-PÉREZ, A., PÉREZ-SANCHEZ, R. \& ENCINASGRANDES, A. 1990. Distribution and biology of Ornithodoros erraticis in parts of Spain affected by African swine fever. Veterinary Record, 126:32-37.

OTESILE, E.B., AJUWAPE, A.T.P., ODEMUYIWA, S.O., AKPAVIE, S.O., OLAIFA, A.K., ODAIBO, G.N., OLALEYE, O.D. \& ADETOSOYE, A.I. 2005. Field and experimental investigations of an outbreak of African swine fever in Nigeria. Revue d'Élevage et de Médecine Vétérinaire des Pays Tropicaux, 58:21-26.

PENRITH, M-L., LOPES PEREIRA, C., LOPES DA SILVA, M.M.R., QUEMBO, C., NHAMUSSO, A. \& BANZE, J. 2007. African swine fever in Mozambique: Review, risk factors and considerations for control. Onderstepoort Journal of Veterinary Research, 74:149-160.

PENRITH, M-L. \& THOMSON, G.R. 2004a. Special factors affecting the control of livestock diseases in sub-Saharan Africa, in Infectious diseases of livestock, $2^{\text {nd }}$ ed., edited by J.A.W. Coetzer \& R.C. Tustin. Cape Town: Oxford University Press.

PENRITH, M-L., THOMSON, G.R. \& BASTOS, A.D.S. 2004b. African swine fever, in Infectious diseases of livestock, $2^{\text {nd }}$ ed., edited by J.A.W. Coetzer \& R.C. Tustin. Cape Town: Oxford University Press.

PENRITH, M-L., THOMSON, G.R., BASTOS, A.D.S., PHIRI, O.C., LUBISI, B.A., BOTHA, B., ESTERHUYSEN, J., DU PLESSIS, E.C., MACOME, F. \& PINTO, F. 2004c. An investigation into natural resistance to African swine fever in domestic pigs from an endemic area in southern Africa. Revue scientifique et technique, Office International des Épizooties, 23:665-677.

PÉREZ-SÁNCHEZ, R., ASTIGARRAGA, A., OLEAGA-SÁNCHEZ, A. \& ENCINAS GRANDES, A. 1994. Relationships between the persistence of African swine fever and the distribution of Ornithodoros erraticus in the province of Salamanca, Spain. Veterinary Record, 135:207-209.

PLOWRIGHT, W., PARKER, J. \& PEIRCE, M.A. 1969. The epizootiology of African swine fever in Africa. Veterinary Record, 85:668-674.

PLOWRIGHT, W., PERRY, C.T. \& GREIG, A., 1974. Sexual transmission of African swine fever virus in the tick, Ornithodoros moubata porcinus Walton. Research in Veterinary Science, 17:106-113. 
PLOWRIGHT, W., PERRY, C.T. \& PIERCE, M.A., 1970. Transovarial infection with African swine fever virus in the argasid tick, Ornithodoros moubata porcinus Walton. Research in Veterinary Science, 11:582-584.

PLOWRIGHT, W., THOMSON, G.R. \& NESER, J.A. 1994. African swine fever, in Infectious diseases of livestock, with special reference to southern Africa, edited by J.A.W. Coetzer, G.R. Thomson \& R.C. Tustin. Cape Town: Oxford University Press.

PUJOLS-ROMEU, J., BADIOLA-SAIZ, J.I., PÉREZ DE ROZAS, A.M., SEGURA-CARDONA, L., SACO-GALVANY, M. 1991. Papel que tinen los cerdos en el mantenimiento y transmision del virus de la PPA. II. Aislamiento del virus de animales seropositivos. Medicina Veterinaria, 8:560-566.

RENNIE, L., WILKINSON, P.J. \& \& MELLOR, P.S. 2001. Transovarial transmission of African swine fever virus in the argasid tick Ornithodoros moubata. Medical and Veterinary Epidemiology, 15:140-146.

ROGER, F., RATOVONJATO, VOLA, P. \& UILENBERG, G. 2001. Ornithodoros porcinus ticks, bushpigs, and African swine fever in Madagascar. Experimental and Applied Acarology, 25:263-269.

SANCHEZ-BOTIJA, A.C. 1963. Reservorios del virus de la peste porcina africana. Investigación del virus de la PPA enlos artrópodos mediante la prueba de la hemoadsorción. Bulletin Office International des Épizooties, 60:895-899.

STEYN, D.G. 1928. Preliminary report on a South African virus disease amongst pigs. $13^{\text {th }}$ and $14^{\text {th }}$ Reports of the Director of Veterinary Education and Research, Union of South Africa: 415-428.

STEYN, D.G. 1932. East African virus disease in pigs. $18^{\text {th }}$ Report of the Director of Veterinary Services and Animal Industry, Union of South Africa, 1:99-109.

THOMSON, G.R. 1985. The epidemiology of African swine fever: the role of free-living hosts in Africa. Onderstepoort Journal of Veterinary Research, 52:201-209.
THOMSON, G.R., GAINARU, M., LEWIS, A., BIGGS, H., NEVILL, E., VAN DER PYPEKAMP, H., GERBER, L., ESTERHUYSEN, J., BENGIS, R., BEZUIDENHOUT, D. \& CONDY, J. 1983. The relationship between African swine fever virus, the warthog and Ornithodoros species in southern Africa, in African swine fever, edited by P.J. Wilkinson. EUR 8466 EN. Commission of the European Communities.

THOMSON, G.R., GAINARU, M.D. \& VAN DELLEN, A.F. 1979. African swine fever. Pathogenicity and immunogenicity of two non-haemadsorbing viruses. Onderstepoort Journal of Veterinary Research, 46:149-154.

THOMSON, G.R., GAINARU, M.D. \& VAN DELLEN, A.F. 1980. Experimental infection of warthog (Phacochoerus aethiopicus) with African swine fever virus. Onderstepoort Journal of Veterinary Research, 47:19-22.

VALADÃO, F.G. 1969. Notas sobre alguns ensaios realizados em porcos sobreviventes de peste suína africana. Anais Serviços veterinários de Moçambique, 12-14:95-100.

VIGÁRIO, J.D., TERRINHA, A.M. \& MOURA NUNES, J.F. 1974. Antigenic relationships among strains of African swine fever. Archiv der Gesellschaft für Virusforschung, 45:272-277.

WESLEY, R.D. \& TUTHILL, A.E. 1984. Genome relatedness among African swine fever virus isolates by restriction endonuclease analysis. Preventive Veterinary Medicine, 2:53-62.

WILKINSON, P.J. 1989. African swine fever virus, in Virus infections of porcines, edited by M.C. Pensaert. Amsterdam: Elsevier.

WILKINSON, P.J., WARDLEY, R.C. \& WILLIAMS, S.M. 1983. Studies in pigs infected with African swine fever virus (Malta/78), in African swine fever, edited by P.J. Wilkinson. EUR. 8466 EN. Commission of the European Communities.

WORLD ORGANISATION FOR ANIMAL HEALTH 1996-2002. www.oie.int/eng/info/en_infold.htm?e1d5.

WORLD ORGANISATION FOR ANIMAL HEALTH 2007, 2008. www.oie.int/wahid-prod/public.php?page=home. 